\title{
ZONASI DAN STRUKTUR KOMUNITAS MANGROVE DI PESISIR KABUPATEN MERAUKE
}

\section{ZONATION AND COMMUNITY STRUCTURE OF MANGROVE IN COASTAL AREA OF MERAUKE DISTRICT}

\author{
Sunarni ${ }^{1}$, Modesta R. Maturbongs ${ }^{1}$, Taslim Arifin² \& Rinny Rahmania² \\ ${ }^{1}$ Fakultas Pertanian - Universitas Musamus, Merauke \\ ${ }^{2}$ Pusat Riset Kelautan - Badan Riset dan SDMKP - KKP \\ Email: rinny.rahmania@kkp.go.id \\ Diterima tanggal: 24 Juli 2019 ; diterima setelah perbaikan: 11 November 2019 ; Disetujui tanggal: 29 November 2019 \\ DOI: http://dx.doi.org/10.15578/jkn.v14i3.7961
}

\begin{abstract}
ABSTRAK
Penelitian ini bertujuan untuk mengetahui zonasi dan struktur ekosistem mangrove di wilayah pesisir Kabupaten Merauke tepatnya di Pantai Payumb Distrik Merauke, Pantai Nasem Distrik Naukenjerai dan muara sungai Kumbe Distrik Semangga pada Oktober 2015. Pantai Nasem dan Pantai Payumb dibagi menjadi 2 zona pengambilan sampling sedangkan stasiun muara Sungai Kumbe dibagi menjadi 3 zona. Ukuran transek 100$150 \mathrm{~m}$ tegak lurus garis pantai dengan ukuran plot $10 \times 10 \mathrm{~m}^{2}$. Pada setiap plot sampling dilakukan perhitungan kerapatan jenis, frekuensi jenis dan indeks dominansi. Berdasarkan hasil penelitian diperoleh 15 jenis mangrove yang tersebar di ketiga stasiun yaitu Pantai Nasem 7 spesies, Pantai Payumb 9 spesies dan muara Sungai Kumbe 13 spesies. Vegetasi mangrove di kawasan penelitian disusun oleh 8 genus dan 15 jenis mangrove. Berdasarkan dominansi jenis vegetasi mangrove, kondisi komunitas di stasiun Pantai Nasem dan Pantai Payumb termasuk dalam kriteria labil dengan tipe substrat berpasir dan dominansi genus Avicennia. Sebaliknya stasiun muara Sungai Kumbe memiliki kondisi komunitas vegetasi yang stabil dengan tipe substrat berlumpur dan dominansi genus Rhizophora. Zonasi ekosistem mangrove pada area pesisir Kabupaten Merauke terdiri dari dua tipe zonasi. Pada daerah pesisir yang berhadapan langsung dengan laut, genus Avicennia merupakan pioneer dalam membentuk zonasi vegetasi mangrove. Sebaliknya pada daerah sungai, genus Rhizophora menjadi pioneer membentuk zonasi pada kedua sisi badan sungai.
\end{abstract}

Kata kunci : zonasi, struktur komunitas, mangrove, distrik Merauke.

\section{ABSTRACT}

This study aims to determine zonation type and mangrove ecosystems structure in coastal areas of Merauke Regency, spesifically in Payumb Beach - Merauke District, Nasem Beach - Naukenjerai District and estuary of Kumbe River - Semangga District in October 2015. Nasem Beach and Payumb Beach are divided into 2 sampling zones while Kumbe River estuary is divided into 3 zones. The transect size is 100-150m located perpendicular to the coastline with a plot size of $10 \times 10 \mathrm{~m}^{2}$. We calculated density, frequency and dominance index in each plot. We found 15 types of mangroves scattered in all sampling zones; 7 spesies were found in Nasem Beach, 9 spesies in Payumb Beach and 13 spesies in estuary of Kumbe River. The mangrove vegetation in the study area was composed of 8 genous and 15 types of mangroves. Based on the dominance type of mangrove vegetation, community conditions at the Nasem Beach and Payumb Beach are included in unstable criteria with sandy substrate and dominated by Avicennia genus. Meanwhile estuary of Kumba River showed a stable vegetation community condition with muddy substrate and dominated by Rhizophora genus. Mangrove ecosystem in the coastal area of Merauke Regency consists of two zonation types. In coastal areas facing the sea directly, Avicennia genus is a pioneer in forming zoning of mangrove vegetation. In contrast to the river area, Rhizophora genus becomes a pioneer on both sides of the river body.

Keywords : zonation, community structure, mangrove, Merauke district. 


\section{PENDAHULUAN}

Hutan mangrove adalah tipe hutan yang khas terdapat di sepanjang pantai atau muara sungai yang masih dipengaruhi oleh pasang surut air laut (FAO, 1982) Ekosistem mangrove sering disebut sebagai hutan payau atau hutan bakau. Hutan mangrove memiliki fungsi sebagai penahan gelombang dan perangkap sedimen. Dari segi ekologi, hutan mangrove mempunyai peranan yang sangat penting sebagai daerah pemijahan dan daerah pembesaran berbagai jenis ikan, udang, kepiting, kerang-kerangan dan organisme lainnya (Nontji, 2005). Selain memiliki berbagai fungsi, mangrove juga membentuk susunan atau distribusi vegetasi mangrove yang dimulai dari arah laut hingga ke arah daratan yang disebut dengan zonasi mangrove.

Berbagai penelitian di berbagai daerah menunjukkan zonasi yang berbeda di setiap daerah atau pulau yang dilihat berdasarkan karakteristik perairan yang mendukung terbentuknya zonasi seperti substrat, salinitas dan pasang surut. Beberapa ahli seperti Chapman (1977) dan Bunt \& Williams (1981), menyatakan bahwa hal tersebut berkaitan erat dengan tipe tanah (lumpur, pasir atau gambut), keterbukaan terhadap hempasan gelombang, salinitas serta pengaruh pasang surut. Pasang surut dan arus yang membawa material sedimen dan substrat yang terjadi secara periodik menyebabkan perbedaaan dalam pembentukan zonasi mangrove.

Di Indonesia, substrat berlumpur sangat baik untuk tegakan Rhizophora mucronata dan Avicennia marina (Kint, 1934). Jenis-jenis lain seperti Rhizopora stylosa tumbuh dengan baik pada substrat berpasir, bahkan pada pulau karang yang memiliki substrat berupa pecahan karang, kerang dan bagian-bagian dari Halimeda (Ding Hou, 1958). Avicennia merupakan marga yang memiliki kemampuan toleransi terhadap kisaran salinitas yang luas dibandingkan dengan marga lainnya. Avicennia marina mampu tumbuh dengan baik pada salinitas yang mendekati tawar sampai dengan 90\%o (MacNae, 1966;1968). Menurut Bengen (2004), daerah yang paling dekat dengan laut atau pada zonasi mangrove terbuka sering ditumbuhi oleh Avicennia sp. dengan tipe substrat agak berpasir.

Hafizh et al., (2013) memberikan contoh perbedaan karakteristik zonasi mangrove melalui hasil perhitungan dominansi mangrove yang dilakukan pada tingkat pohon, pancang dan semai dan juga berasal dari perhitungan kerapatan zonasi mangrove di Kampung
Gisi yang terbagi dalam 3 zona mangrove dengan kisaran salinitas 20-30\%o yaitu:

1. Zona I atau zona yang lokasinya berada dekat dengan area laut ditumbuhi atau didominasi oleh jenis Rhizopora apiculata dan dapat dijumpai Xylocarpus granatum, Scyphiphora hydrophyllacea dan Sonneratia alba dengan kisaran salinitas 25-30\%o.

2. Zona II atau zona tengah ditumbuhi atau didominasi oleh jenis Scyphiphora hydrophyllacea dan dapat dijumpai Xylocarpus granatum serta Lumnitzera littorea dengan kisaran salinitas 23-27\%o.

3. Zona III atau zona yang dekat ke arah daratan ditumbuhi atau didominasi oleh jenis Lumnitzera littorea diselingi dengan Scyphiphora hydrophyllacea dengan kisaran salinitas 21-27\% .

Papua merupakan salah satu daerah yang memiliki area hutan mangrove terbesar di Indonesia yakni sekitar 1.350.600 ha (Hartini et al., 2010). Salah satu bagian dari Papua adalah daerah Kabupaten Merauke dengan luas wilayah daratan $45.075 \mathrm{~km}^{2}$ dan luas perairan laut $75.000 \mathrm{~km}^{2}$, merupakan wilayah yang relatif rata dan berawa yang terbentuk dari endapan sedimen alluvial dengan kondisi dataran yang rendah dengan kemiringan $0-8^{\circ}$ (BKPMD, 2009). Kabupaten Merauke yang terletak di ujung selatan Papua memiliki ekosistem mangrove yang sangat luas, sebagaimana dilaporkan oleh WWF pada tahun 2005 dengan luasan 216,196 ha. Menurut data yang dirilis oleh Pemerintah Kabupaten Merauke tahun 2009, Kabupaten Merauke memiliki luasan hutan mangrove 4.672,382 ha.

Pantai Payumb Distrik Merauke dan Pantai Nasem Distrik Naukenjerai merupakan wilayah pesisir Kabupaten Merauke yang memiliki keunikan dan potensi sumberdaya hayati laut dan mangrove yang potensial begitu pula dengan Desa Kumbe yang memiliki potensi sumberdaya estuari yang potensial dan didukung oleh keberadaan hutan mangrove yang masih alami. Dengan karakteristik perairan yang berbeda-beda antara satu daerah dengan daerah lainnya maka di setiap daerah atau pulau akan memiliki zonasi dan struktur mangrove yang khas dan berbeda, seperti halnya yang terdapat di Kabupaten Merauke. Walaupun demikian, hingga saat ini belum ada penelitian mengenai zonasi dan struktur mangrove yang dilakukan di Kabupaten Merauke. Berdasarkan kondisi di atas, perlu dilakukan studi tentang zonasi dan struktur ekosistem mangrove di wilayah pesisir pantai dan muara sungai Kabupaten Merauke pada tiga distrik yakni Distrik Merauke, Distrik Semangga dan Distrik Noukenjerai. 
Tujuan penelitian ini adalah untuk mengetahui zonasi dan struktur ekosistem mangrove di wilayah pesisir dan muara sungai yang ada di Kabupaten Merauke. Penelitian ini dapat dijadikan sebagai bahan bagi penelitian lanjutan serta menambah ilmu pengetahuan dan referensi mengenai zonasi dan struktur ekosistem mangrove di wilayah pesisir pantai dan muara sungai yang ada di Kabupaten Merauke.

\section{BAHAN DAN METODE}

\section{Waktu dan Tempat}

Penelitian ini dilaksanakan pada bulan Oktober 2015 pada tiga distrik yaitu Distrik Merauke, Distrik Semangga dan Distrik Noukenjerai (Gambar 1).

\section{Alat dan Bahan}

Alat yang digunakan selama kegiatan penelitian adalah GPS, rol meter, tali rafia, kayu patok, gunting, kamera digital, kantong plastik, label, tissue, alat tulis dan buku identifikasi mangrove.

\section{Prosedur Penelitian}

\section{Mekanisme pengukuran mangrove}

Lokasi penelitian dipilih berdasarkan keberadaan vegetasi mangrove. Pada setiap lokasi penelitian ditentukan stasiun pengamatan. Pada setiap stasiun pengamatan, ditetapkan transek garis dari arah laut ke arah darat (tegak lurus garis pantai) sepanjang zonasi hutan mangrove dengan panjang transek 100$150 \mathrm{~m}$. Sepanjang transek garis, diletakkan secara acak petak-petak contoh (plot) berbentuk bujur sangkar dengan ukuran $10 \times 10 \mathrm{~m}^{2}$ yang ditempatkan sepanjang garis transek. Jarak antar transek 100m (Gambar 2). Pada setiap stasiun dibagi menjadi $2-3$ zona areal pengambilan sampling. Pantai Nasem dan Payumb terbagi menjadi 2 zona, sedangkan areal penelitian untuk stasiun muara Sungai Kumbe terbagi menjadi 3 zona. Pembagian zona ini dilakukan berdasarkan pengamatan karakteristik vegetasi mangrove secara visual.

\section{Mekanisme identifikasi mangrove}

Identifikasi jenis mangrove dilakukan dengan cara melihat bentuk/karakteristik/ciri umum dari bentuk pohon, bentuk akar, bentuk buah dan bentuk bunga. Untuk mengurangi tingkat kesalahan dalam pengidentifikasian kita dapat menggunakan gambar/ referensi jenis-jenis dari buku atau literatur spesies mangrove yang ada. Data ini kemudian ditulis dalam tabel pengamatan yang kemudian akan dideskripsikan lebih lanjut.

\section{Analisa Data \\ Kerapatan Jenis}

Menurut Bengen (2004), kerapatan jenis merupakan perbandingan antara jenis i (ni) dengan jumlah luas total area pengambilan contoh (A), dengan formula sebagai berikut:

$D_{i}=n_{i} / A$

dimana, $\mathrm{D}_{\mathrm{i}}=$ kerapatan jenis ke- $\mathrm{i}, \mathrm{n}_{\mathrm{i}}=$ jumlah total tegakan jenis ke-i, $\mathrm{A}=$ luas total area pengambilan contoh (luas total petak contoh/plot).

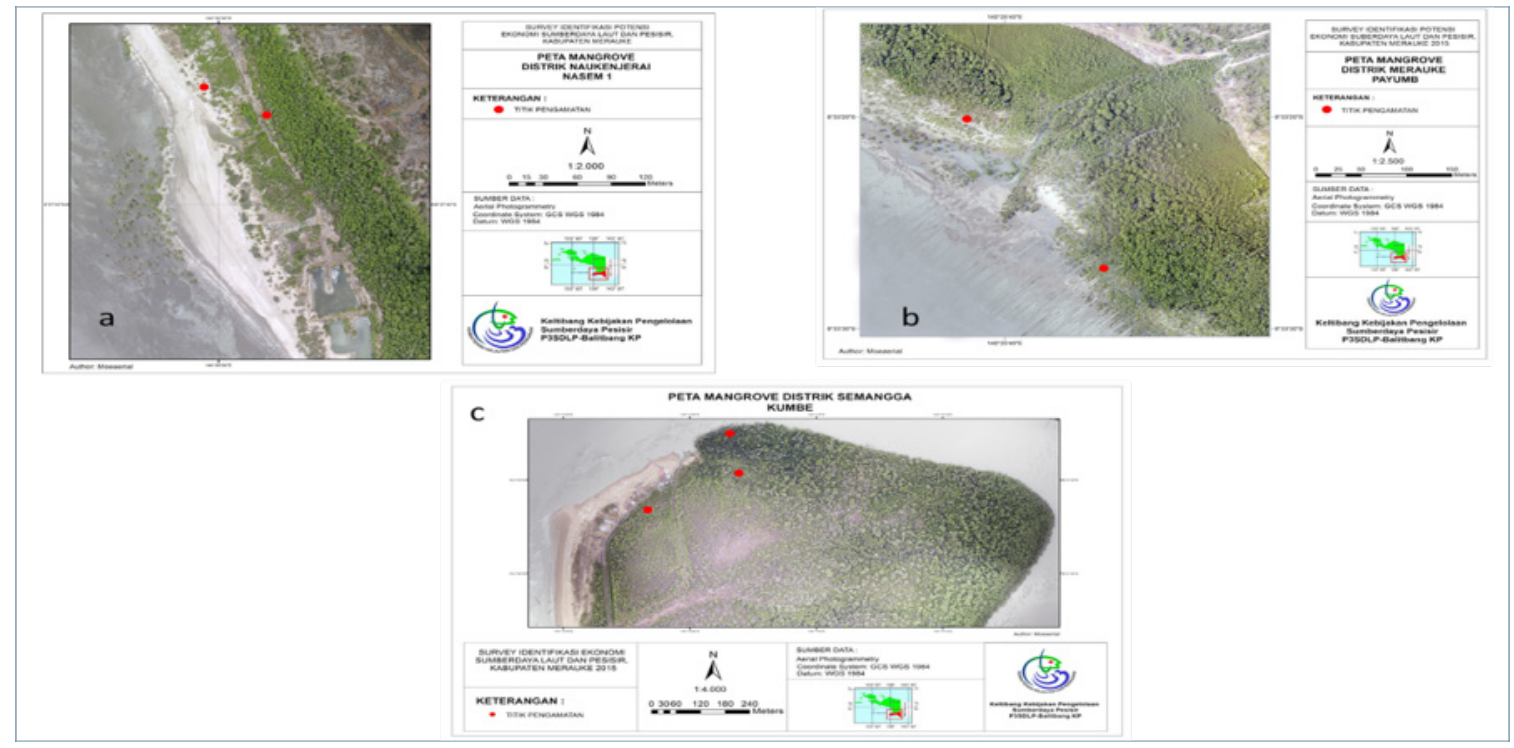

Gambar 1. Lokasi penelitian: a) Distrik Merauke, b) Distrik Naukenjerai, c) Distrik Semangga. Figure 1. Research sites: a) Merauke District, b) Naukenjerai District, c) Semangga District. 

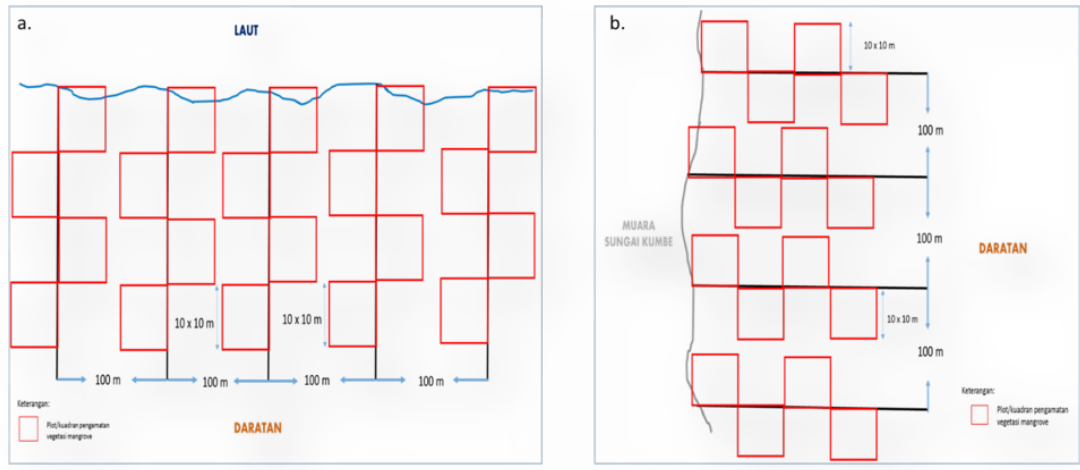

Gambar 2. Desain pengamatan vegetasi mangrove.

Figure 2. Design of mangrove vegetation observation.

\section{Kerapatan Relatif Jenis}

Kerapatan relatif jenis $\left(\mathrm{RD}_{\mathrm{i}}\right)$ adalah perbandingan antara jumlah tegakan jenis $i\left(n_{i}\right)$ dan jumlah total tegakan seluruh jenis $\left(\sum n\right)$.

$\mathrm{RD}_{\mathrm{i}}=\left(\mathrm{n}_{\mathrm{i}} / \sum \mathrm{n}\right) \times 100$

Frekuensi Jenis $\left(\mathrm{F}_{\mathrm{i}}\right)$

Frekuensi jenis $\left(\mathrm{F}_{\mathrm{i}}\right)$ adalah peluang ditemukannya jenis i dalam plot yang diamati.

$\mathrm{F}_{\mathrm{i}}=\mathrm{P}_{\mathrm{i}} / \sum \mathrm{P}$

dimana $\mathrm{Fi}$ adalah frekuensi jenis $\mathrm{i}, \mathrm{P}_{\mathrm{i}}$ adalah jumlah plot dimana ditemukan jenis $\mathrm{i}$ dan $\mathrm{P}$ adalah jumlah total plot yang diamati.

Frekuensi Relatif Jenis $\left(\mathrm{RF}_{\mathrm{i}}\right)$

Frekuensi relatif jenis $\left(\mathrm{RF}_{\mathrm{i}}\right)$ adalah perbandingan antara frekuensi jenis $i\left(\mathrm{~F}_{\mathrm{i}}\right)$ dan jumlah frekuensi untuk seluruh jenis $\left(\sum F\right)$.

$\mathrm{RF}_{\mathrm{i}}=\left(\mathrm{F}_{\mathrm{i}} / \sum \mathrm{F}\right) \times 100$

Indeks Dominansi

Status kondisi komunitas dapat ditentukan dengan menggunakan indeks dominansi (Fachrul, 2007) sebagai berikut:

$D=\sum_{i=1}^{s}\left[\frac{N i}{N}\right]^{2}$

$\mathrm{D}=$ Indeks dominansi-Simpson; $\mathrm{N}_{\mathrm{i}}=$ Jumlah individu jenis ke-i; $\mathrm{N}=$ Jumlah total individu; $\mathrm{S}=$ Jumlah jenis

Keterangan :
Indeks dominansi-Simpson ini bernilai antara 0 - 1 dengan deskripsi sebagai berikut (Samsumarlin et al., 2015) :

$\mathrm{D}=0$ berarti tidak terdapat jenis yang mendominasi jenis lainnya atau komunitas berada dalam kondisi stabil.

$\mathrm{D}=1$ berarti terdapat jenis yang mendominasi jenis lainnya atau komunitas berada dalam kondisi labil karena terjadi tekanan ekologis.

\section{HASIL DAN PEMBAHASAN}

\section{Komposisi Jenis}

Mangrove yang tumbuh di tiga distrik Kabupaten Merauke merupakan hutan mangrove yang masih terbentuk secara alami. Vegetasi mangrove yang ditemukan pada saat sampling terbagi dalam tiga kriteria yaitu pohon, anakan dan semai berdasarkan ukuran diameter batangnya. Menurut Bengen (2004), yang termasuk dalam kriteria pohon memiliki diameter $>4 \mathrm{~cm}$, anakan memiliki diameter $<4 \mathrm{~cm}$ tinggi $1 \mathrm{~m}$ dan semai memiliki tinggi $<1 \mathrm{~m}$.

Berdasarkan hasil penelitian diperoleh 15 jenis mangrove yang tersebar di ketiga stasiun (Tabel 1). Pada Pantai Nasem diperoleh 7 spesies mangrove, yaitu: Avicennia alba, A. eucalyptifolia, Aegialitis annulata, Aegiceras floridum, Bruguiera cylindrica, Acanthus ilicifolius dan Sonneratia alba dimana pada bagian depan didominasi oleh jenis Avicennia sp., selanjutnya pada Pantai Payumb diperoleh 9 spesies mangrove yaitu: Avicennia alba, A. eucalyptifolia, Aegialitis annulata, Aegiceras floridum, Bruguiera cylindrica, Acanthus ebracteatus, Rhizophora alba, $R$. stylosa dan Sonneratia alba. Seperti halnya Pantai Nasem, jenis mangrove yang ditemukan berada paling depan dalam zona mangrove yaitu jenis Avicennia $s p$. Komposisi jenis mangrove pada pesisir pantai 
Tabel 1. Kriteria persen tutupan karang

Table 1. Criteria for percent coral cover

\begin{tabular}{|c|c|c|c|c|}
\hline No & Jenis Mangrove & $\begin{array}{l}\text { Stasiun I } \\
\text { (Nasem) }\end{array}$ & $\begin{array}{l}\text { Stasiun II } \\
\text { (Payumb) }\end{array}$ & $\begin{array}{l}\text { Stasiun II } \\
\text { (Kumbe) }\end{array}$ \\
\hline 1 & Avicennia alba & $\sqrt{ }$ & $\sqrt{ }$ & $\sqrt{ }$ \\
\hline 2 & Avicennia eucalyptifolia & $\sqrt{ }$ & $\sqrt{ }$ & $\sqrt{ }$ \\
\hline 3 & Aegialitis annulata & $\sqrt{ }$ & $\sqrt{ }$ & $\sqrt{ }$ \\
\hline 4 & Aegiceras floridum & $\sqrt{ }$ & $\sqrt{ }$ & $\sqrt{ }$ \\
\hline 5 & Acanthus ebracteatus & & $\sqrt{ }$ & \\
\hline 6 & Acanthus ilicifolius & $\sqrt{ }$ & & $\sqrt{ }$ \\
\hline 7 & Bruguiera cylindrica & $\sqrt{ }$ & $\sqrt{ }$ & $\sqrt{ }$ \\
\hline 8 & Bruguiera gymnorrhiza & & & $\sqrt{ }$ \\
\hline 9 & Bruguiera hainesii & & & $\sqrt{ }$ \\
\hline 10 & Bruguiera sexangula & & & $\sqrt{ }$ \\
\hline 11 & Ceriops decandra & & & $\sqrt{ }$ \\
\hline 12 & Rhizophora alba & & $\sqrt{ }$ & \\
\hline 13 & Rhizophora mucronata & & & $\sqrt{ }$ \\
\hline 14 & Rhizophora stylosa & & $\sqrt{ }$ & $\sqrt{ }$ \\
\hline \multirow[t]{2}{*}{15} & Sonneratia alba & $\sqrt{ }$ & $\sqrt{ }$ & $\sqrt{ }$ \\
\hline & Jumlah Jenis/Stasiun & 7 & 9 & 13 \\
\hline
\end{tabular}

Nasem dan Payumb didominasi oleh Avicennia sp., hal ini disebabkan daerah ini merupakan area pesisir pantai yang berhadapan langsung dengan laut dimana daerah yang paling dekat dengan laut atau pada zonasi mangrove terbuka sering ditumbuhi oleh Avicennia sp. dengan tipe substrat agak berpasir (Bengen, 2004). Dari beberapa hasil penelitian diketahui bahwa Avicennia marina dapat tumbuh pada substrat yang berpasir kasar, halus maupun lumpur yang dalam (Halidah, 2013 dan Kusmana et al., 2003, Aini et al., 2015). Van Steenis dalam Khazali (2006) menjelaskan bahwa Sonneratia alba dan Avicennia alba merupakan jenis-jenis dominan pada areal pantai yang sangat tergenang.

Jenis mangrove di muara Sungai Kumbe merupakan yang paling banyak dibandingkan dengan kedua stasiun sebelumnya yakni 13 jenis mangrove yang terdiri dari Avicennia. alba, A. eucalyptifolia, Aegialitis annulata, Aegiceras floridum, Bruguiera cylindrica, B. gymnorrhiza, B. hainesii, B. sexangula, Ceriops decandra, Acanthus ilicifolius, R. mucronata, $R$. stylosa dan Sonneratia alba. Jenis Rhizophora sp. banyak ditemukan di sepanjang aliran Sungai Kumbe, tepatnya tumbuh dengan subur dan padat di bagian tepi badan Sungai Kumbe. Dengan demikian maka jenis mangrove yang tumbuh di pesisir pantai berbeda dengan jenis mangrove yang tumbuh pada daerah muara sungai, hal ini dikarenakan tipe substrat yang ada di pesisir pantai berbeda dengan tipe substrat yang ada di muara sungai.
Komposisi dan sebaran jenis mangrove pada muara Sungai Kumbe memiliki struktur jenis yang berbeda dengan pesisir Pantai Nasem dan Payumb. Pada muara sungai jenis mangrove yang pertama dijumpai adalah jenis Rhizophora $s p$. dikarenakan daerah tersebut merupakan muara sungai dengan tipe subtrat berlumpur, hal ini sesuai dengan penelitian yang dilakukan oleh Hafizh et al., (2013) dan Lestari (2014) tentang penyebaran jenis mangrove berdasarkan karakteristik substrat pada muara sungai, dimana Rhizophora $s p$. tersebar pada daerah muara sungai. Avicennia marina dan Rhizophora mucronata cenderung untuk mendominasi daerah yang lebih berlumpur (Van Steenis dalam Khazali 2006). Meskipun demikian, genus Sonneratia akan berasosiasi dengan Avicennia jika tanah lumpurnya kaya akan bahan organik (Kantor Menteri Negara Lingkungan Hidup, 1993).

Kerapatan Jenis dan Kerapatan Relatif Jenis Mangrove Kerapatan jenis mangrove merupakan jumlah individu mangrove yang ditemukan dibagi dengan luas area pengamatan. Nilai kerapatan menunjukkan pola penyesuaian suatu jenis dengan lingkungannya, jenis dengan nilai kerapatan tinggi memiliki pola penyesuaian yang besar (Fachrul, 2007). Dengan menghitung kerapatan jenis mangrove, maka akan terlihat jenis-jenis yang ditemukan pada lokasi penelitian. Dengan demikian maka distribusi dari masing-masing jenis dapat terlihat dengan jelas. Gambar 3 menunjukkan kerapatan jenis pada Pantai Nasem, pada zona I dan II jenis mangrove yang 
memiliki nilai kerapatan jenis tertinggi dari genus Avicennia yakni sebesar $0,128 \mathrm{ind} / \mathrm{m}^{2}$ pada zona $\mathrm{I}$, sedangkan pada zona II sebesar $0,11 \mathrm{ind} / \mathrm{m}^{2}$. Jenis mangrove yang memiliki kerapatan jenis terendah pada zona I diperoleh dari genus Acanthus sebesar 0,03 ind $/ \mathrm{m}^{2}$, begitu pula pada zona II kerapatan yang paling rendah diperoleh dari Acanthus sebesar 0,018 ind $/ \mathrm{m}^{2}$.

Nilai kerapatan relatif jenis mangrove tertinggi pada Pantai Nasem juga diperoleh dari genus Avicennia pada zona I maupun II yaitu $47,11 \%$ dan $53,10 \%$. Nilai kerapatan relatif terendah diperoleh dari genus Aegialitis sebesar 8,61\% pada zona I dan Acanthus sebesar $8,27 \%$ pada zona II (Gambar 3).

Pembagian zona pengambilan sampel jenis mangrove pada Pantai Payumb seperti halnya pada Pantai Nasem yaitu terbagi menjadi dua zona yaitu zona I dan II. Nilai kerapatan jenis mangrove tertinggi sama seperti pada Pantai Payumb yakni diperoleh dari genus Avicennia sebesar $0,11 \mathrm{ind} / \mathrm{m}^{2}$ pada zona I dan nilai terendah 0,02 ind $/ \mathrm{m}^{2}$ diperoleh dari genus Sonneratia. Pada zona kedua nilai kerapatan jenis tertinggi diperoleh dari genus Aegialitis sebesar $0,12 \mathrm{ind} / \mathrm{m}^{2}$, sedangkan nilai kerapatan terendah $0,01 \mathrm{ind} / \mathrm{m}^{2}$ diperoleh dari genus Aegiceras (Gambar 5).

Untuk nilai kerapatan relatif jenis tertinggi pada zona I diperoleh dari genus Avicennia sebesar 51,74\%. Sebaliknya pada zona II nilai tertinggi diperoleh dari genus Aegialitis sebesar 30,87\% kemudian diikuti oleh Avicennia sebesar 28,22\%. Genus Sonneratia merupakan jenis yang memiliki nilai kerapatan relatif jenis terendah sebesar $10,51 \%$ pada zona I, sedangkan pada zona II nilai terendah didapat dari genus Aegiceras sebesar $2,53 \%$.

Kerapatan jenis mangrove muara Sungai Kumbe pada stasiun I hanya terdiri dari satu jenis mangrove dari genus Rhizophora dengan nilai kerapatan jenis 2,58 ind $/ \mathrm{m} 2$ dan kerapatan relatif jenis $100 \%$ (Gambar 7). Tingginya kerapatan genus Rhizophora pada bagian sisi badan Sungai Kumbe sesuai dengan penjelasan Usman et al., (2013), Darmadi \& Khan (2012), pertumbuhan genus Rhizophora di Pulau Dudepo dari jenis Rhizophora mucronata yang memiliki kerapatan relatif tertinggi karena kondisi substrat yang umumnya lumpur mengandung bahan organik yang sangat cocok untuk mendukung pertumbuhan jenisnya, selain itu jenis ini merupakan tumbuhan perintis atau pioneer.

Pada stasiun II terdapat delapan jenis mangrove dimana jenis mangrove yang memiliki nilai kerapatan

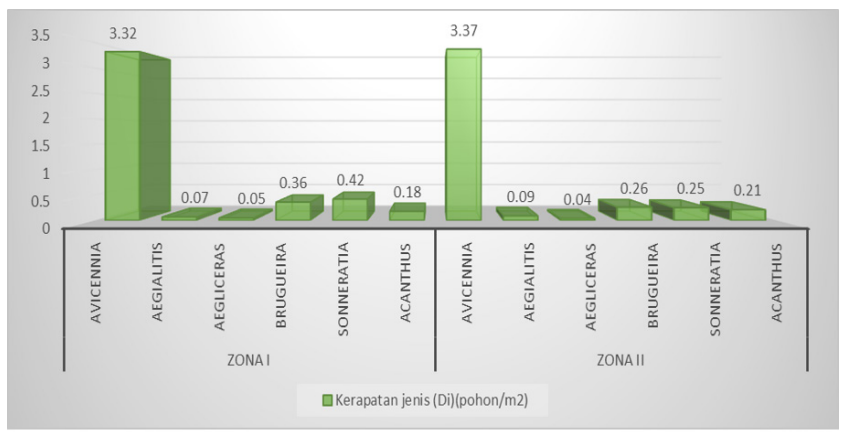

Gambar 3. Grafik kerapatan jenis (ind $/ \mathrm{m}^{2}$ ) mangrove Pantai Nasem.

Figure 3. Graph of species density (ind $/ \mathrm{m}^{2}$ ) mangrove of Nasem Beach.

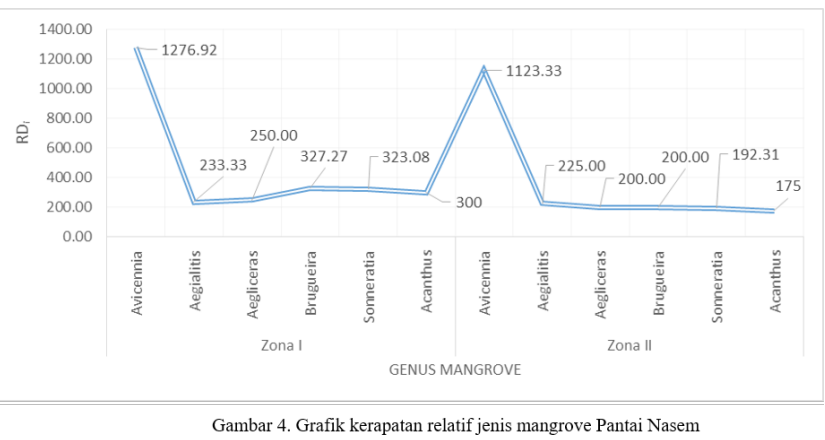

Gambar 4. Grafik kerapatan relatif jenis mangrove Pantai Nasem.

Figure 4. Graph of relative density of mangrove species in Nasem Beach.

jenis tertinggi yakni dari genus Avicennia sebesar 1,72 ind $/ \mathrm{m}^{2}$ dan nilai kerapatan jenis mangrove yang paling rendah diperoleh dari genus Aegialitis sebesar 0,06 ind/ $\mathrm{m}^{2}$.

Kerapatan jenis dan kerapatan relatif jenis tertinggi pada zona II diperoleh dari genus yang sama yaitu Avicennia yakni sebesar $59,72 \%$ dan kerapatan relatif terendah ditemukan pada genus Aegialitis sebesar 2,08\%. Sedangkan pada stasiun III kerapatan jenis mangrove yang paling mendominasi adalah dari genus Avicennia sebesar 3,12 ind $/ \mathrm{m}^{2}$, dan yang paling rendah adalah genus Aegiceras sebesar $0,01 \mathrm{ind} / \mathrm{m}^{2}$. Berdasarkan hasil analisis di atas, kerapatan jenis dan kerapatan relatif jenis vegetasi mangrove tertinggi diperoleh dari genus Rhizophora pada muara Sungai Kumbe sebab jenis ini selalu ditemukan pada kategori pohon dan jarang ditemukan pada tingkat semai. Hal ini didukung dengan pernyataan Usman et al., (2013), mangrove yang memiliki kerapatan tertinggi terdapat pada kategori pohon yang menyebabkan cahaya matahari yang masuk tidak dapat menyinari lahan hutan mangrove sehingga membuat semai dan pancang tidak tumbuh dengan baik. Secara umum hasil 


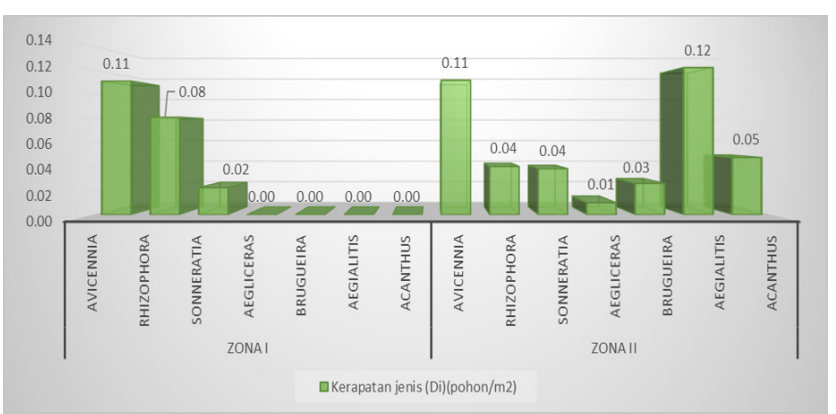

Gambar 5. Grafik kerapatan jenis (ind $/ \mathrm{m}^{2}$ ) mangrove Pantai Payumb.

Figure 5. Graph of species density (ind $/ \mathrm{m}^{2}$ ) mangrove Payumb Beach.

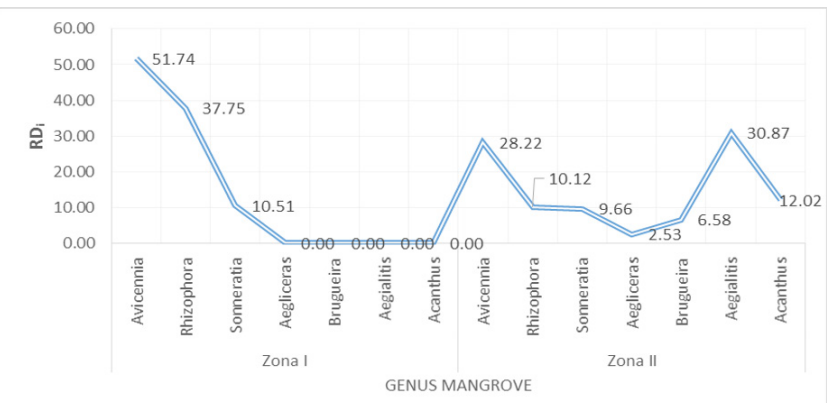

Gambar 6. Grafik kerapatan relatif jenis mangrove Pantai Payumb.

Figure 6. Graph of relative density of mangrove species in Payumb Beach.

pengamatan pada ketiga stasiun menunjukkan bahwa genus Avicennia memiliki nilai total kerapatan yang paling tinggi sebanyak 669 individu pada stasiun Pantai Nasem, 578 individu di stasiun pengamatan Pantai Payumb dan 484 individu di stasiun pengamatan muara Sungai Kumbe. Jenis A. alba paling banyak ditemukan, hal ini menunjukkan jenis ini memiliki kemampuan untuk tumbuh dan berkembang dengan baik di lokasi tersebut (Fadli et al., 2015 dan Haya et al., 2015).

\section{Frekuensi Jenis dan Frekuensi Relatif Jenis Mangrove}

Tabel 2 menunjukkan nilai frekuensi jenis dan frekuensi relatif jenis dari beberapa genus vegetasi mangrove yang ditemukan pada ketiga stasiun pengamatan. Dari hasil analisis pada stasiun pengamatan di Pantai Nasem dan Payumb yang memiliki vegetasi mangrove menunjukkan nilai frekuensi jenis dan frekuensi relatif yang tertinggi diperoleh dari genus Avicennia. Nilai frekuensi jenis genus Avicennia pada stasiun Pantai Nasem sebesar 0,87 pada Zona I dengan frekuensi relatif $42,62 \%$. Pada Zona II sebesar 1 dengan frekuensi relatif jenis dari genus ini sebesar 40,54\%. Frekuensi jenis genus Avicennia pada stasiun pengamatan di Pantai
Payumb untuk Zona I dan II memiliki nilai yang sama sebesar 0,87. Frekuensi relatif jenis genus Avicennia memiliki persentase tertinggi dibandingkan genus lainnya yakni sebesar $61.90 \%$. Hal ini terjadi karena pada Zona I hanya ditemukan dua genus mangrove yaitu Avicennia dan Rhizophora yang didominasi oleh kehadiran dari genus Avicennia.

Tingginya frekuensi genus Avicennia pada kedua stasiun ini disebabkan oleh kondisi lingkungan yang merupakan lokasi yang berhadapan langsung dengan laut terbuka. Kondisi lingkungan pada kedua stasiun tersebut dipengaruhi oleh faktor pasang surut dengan tingkat salinitas yang tinggi yang merupakan pendukung dari keberhasilan genus Avicennia untuk bertahan hidup. Hal ini didukung oleh pernyataan Noor et al. (2006) yang menyatakan bahwa Avicennia merupakan genus yang memiliki kemampuan toleransi terhadap kisaran salinitas yang luas dibandingkan dengan genus lainnya. Selain itu berdasarkan preferensi tempat hidup, jenis ini merupakan salah satu mangrove yang tersebar luas di dekat pantai ke arah lebih ke depan (ke arah laut) serta tumbuh dengan baik pada substrat yang agak lembut (Suryawan, 2007).

Stasiun muara Sungai Kumbe memiliki zona pengamatan frekuensi jenis vegetasi mangrove yang unik dimana pada Zona I hanya ditumbuhi oleh jenis vegetasi mangrove dari genus Rhizophora. Nilai frekuensi jenis pada zona ini sebesar 8,6 dan frekuensi relatif sebesar $100 \%$. Nilai frekuensi genus yang tinggi pada zona ini akibat kondisi lingkungan yang terletak pada bagian sisi badan Sungai Kumbe sehingga substrat pada areal ini berlumpur dan tebal. Kondisi lingkungan tersebut mendukung genus ini tumbuh dengan subur dan melimpah. Hal tersebut sesuai dengan pernyataan Rahman et al., (2014) yang menyatakan bahwa genus Rhizophora lebih menyukai substrat yang mengandung lumpur.

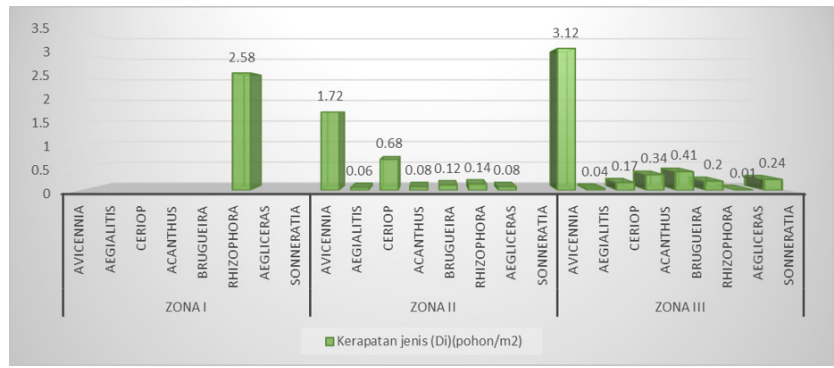

Gambar 7. Grafik kerapatan jenis (ind $/ \mathrm{m}^{2}$ ) mangrove muara Sungai Kumbe.

Figure 7. Graph of species density (ind $/ \mathrm{m}^{2}$ ) of mangroves in the Kumbe River estuary. 
Tabel 2. Frekuensi jenis dan frekuensi relatif jenis mangrove

Table 2. Specific frequency and relative frequency of mangrove species

\begin{tabular}{llllllll}
\hline Keterangan & \multicolumn{2}{c}{ Pantai Nasem } & \multicolumn{2}{c}{ Pantai Payumb } & \multicolumn{2}{c}{ Muara Sungai Kumbe } \\
Zona & Genus & Fi & RFi (\%) & Fi & Rfi $(\%)$ & Fi & Rfi (\%) \\
\hline Zona I & Acanthus & 0,2 & 9,84 & - & - & - & - \\
& Aegialitis & 0,1 & 4,92 & - & - & - & - \\
& Aegiceras & 0,07 & 3,28 & - & - & - & - \\
Avicennia & 0,87 & 42,62 & 0,87 & 61,90 & - & - \\
Bruguiera & 0,37 & 18,03 & - & - & - & - \\
Ceriops & - & - & - & - & - & - \\
Rhizophora & - & - & 0,4 & 28,57 & 8,6 & 100 \\
Sonneratia & 0,43 & 21,31 & 0,13 & 9,52 & - & - \\
Zona II & Acanthus & 0,4 & 16,22 & 0,13 & 6,35 & 0,17 & 6,25 \\
Aegialitis & 0,13 & 5,41 & 0,17 & 7,94 & 0,20 & 7,5 \\
Aegiceras & 0,07 & 2,70 & 0,17 & 7,94 & 0,27 & 10 \\
Avicennia & 1 & 40,54 & 0,87 & 41,27 & 0,93 & 35 \\
Bruguiera & 0,43 & 17,57 & 0,33 & 15,87 & 0,27 & 10 \\
Ceriops & - & - & - & & - & 0,67 & 25 \\
Rhizophora & - & - & 0,07 & 3,17 & 0,17 & 6,25 \\
Sonneratia & 0,43 & 17,57 & 0,37 & 17,46 & - & - \\
Zona III Acanthus & - & - & - & - & 0,50 & 15,63 \\
Aegialitis & - & - & - & - & 0,13 & 4,17 \\
Aegiceras & - & - & - & - & 0,03 & 1,04 \\
Avicennia & - & - & - & - & 1,00 & 31,25 \\
Bruguiera & - & - & - & - & 0,63 & 19,79 \\
Ceriops & - & - & - & - & 0,20 & 6,25 \\
Rhizophora & - & - & - & - & 0,40 & 12,5 \\
Sonneratia & - & - & -30 & 9,38 \\
\hline
\end{tabular}

Untuk Zona II dan III pada stasiun muara Sungai Kumbe memiliki kondisi yang sama seperti stasiun Pantai Nasem dan Pantai Payumb dimana nilai frekuensi jenis dan frekuensi relatif tertinggi diperoleh dari genus Avicennia. Berbeda pada Zona I, tingginya frekuensi genus Avicennia pada kedua zona ini disebabkan oleh lokasi pengamatan vegetasi yang berada 200 m dari sisi Sungai Kumbe dan berada pada bagian depan menghadap laut. Kondisi tersebut sejalan dengan pernyataan Simbala (2007) dalam Yuningsih et al., (2013) menjelaskan bahwa jenis yang memiliki nilai frekuensi dan nilai kerapatan tertinggi merupakan kategori jenis yang memiliki kemampuan adaptasi yang baik terhadap kondisi lingkungan.

\section{Status Komunitas Vegetasi Mangrove}

Hasil analisis vegetasi untuk tingkat dominansi dalam menentukan status komunitas vegetasi mangrove tersaji pada Tabel 3. Dari nilai dominansi genus menunjukkan vegetasi mangrove pada stasiun Pantai Nasem dan Pantai Payumb didominansi oleh genus Avicennia dengan nilai masing-masing stasiun 0,602 dan 0,468 berturut-turut. Nilai dari indeks dominansi ini berdasarkan kriteria Samsumarlin et al., (2015) yang menunjukkan adanya dominansi dari genus tersebut. Berdasarkan kriteria tersebut, nilai indeks dominansi mendekati 1 yang menunjukkan kondisi komunitas vegetasi mangrove pada kedua stasiun masuk dalam kondisi labil.

Dominansi dari genus Avicennia menunjukkan jenis dari genus ini mampu bertahan dan dominan pada stasiun Pantai Nasem dan Pantai Payumb dengan kondisi lingkungan yang ekstrim seperti ombak, arus pasang surut, kondisi pasang dan surut yang relatif jauh, cuaca panas yang ekstrim serta dampak dari aktivitas manusia yaitu perusakan hutan akibat penggalian pasir. Hal ini didukung dengan hasil penelitian Jamili et al., (2009) di Pulau Kaledupa yang menunjukkan faktor ombak yang kuat akibat tiupan angin yang cukup kencang, juga berpengaruh terhadap keberhasilan propagul menjadi semai. Rabinowiz (1978) dalam Jamili et al., (2009), menjelaskan lebih lanjut bahwa aktivitas pasang surut mampu membawa berbagai propagul dari semua ukuran dan jenis ke semua bidang zona pasang surut. 
Tabel 2. Status vegetasi mangrove pada tiga stasiun berdasarkan Indeks Dominansi

Table 2. Mangrove vegetation status at three stations is based on Dominance Index

\begin{tabular}{|c|c|c|c|c|c|c|}
\hline \multirow{2}{*}{$\begin{array}{l}\text { Keterangan } \\
\text { Genus }\end{array}$} & \multicolumn{2}{|c|}{ Pantai Nasem } & \multicolumn{2}{|c|}{ Pantai Payumb } & \multicolumn{2}{|c|}{ Muara Sungai Kumbe } \\
\hline & D & Kategori & D & Kategori & D & Kategori \\
\hline Acanthus & \multicolumn{2}{|l|}{0,002} & \multicolumn{2}{|l|}{0,001} & \multicolumn{2}{|l|}{0,0018} \\
\hline Aegialitis & \multicolumn{2}{|c|}{0,0003} & \multicolumn{2}{|c|}{0,005} & \multicolumn{2}{|l|}{0,0001} \\
\hline Aegiceras & \multicolumn{2}{|l|}{0,0001} & \multicolumn{2}{|c|}{0,00004} & \multicolumn{2}{|l|}{0,0001} \\
\hline Avicennia & 0,602 & Dominan & 0,468 & Dominan & 0,235 & Tidak ada spesies \\
\hline Bruguiera & \multicolumn{2}{|l|}{0,005} & \multicolumn{2}{|c|}{0,0009} & 0,003 & yang mendominansi \\
\hline Ceriops & \multicolumn{2}{|l|}{-} & \multicolumn{2}{|c|}{-} & \multicolumn{2}{|l|}{0,007} \\
\hline Rhizophora & \multicolumn{2}{|l|}{-} & \multicolumn{2}{|l|}{0,015} & \multicolumn{2}{|l|}{0,085} \\
\hline Sonneratia & \multicolumn{2}{|l|}{0,006} & \multicolumn{2}{|l|}{0,004} & \multicolumn{2}{|l|}{0,001} \\
\hline Status & \multirow{2}{*}{\multicolumn{2}{|c|}{$\begin{array}{l}\text { Kondisi Komunitas } \\
\text { Labil }\end{array}$}} & \multirow{2}{*}{\multicolumn{2}{|c|}{$\begin{array}{l}\text { Kondisi Komunitas } \\
\text { Labil }\end{array}$}} & \multirow{2}{*}{\multicolumn{2}{|c|}{$\begin{array}{l}\text { Kondisi Komunitas } \\
\text { Stabil }\end{array}$}} \\
\hline Komunitas & & & & & & \\
\hline
\end{tabular}

Genus Avicennia pada stasiun muara Sungai Kumbe memiliki nilai indeks dominansi 0,235 dimana nilai ini lebih rendah dibandingkan dengan dua stasiun sebelumnya dikarenakan kondisi substrat pada stasiun pengamatan yang berlumpur. Hal ini merujuk pada pernyataan Indah et al., (2009) dalam Habdiansyah et al., (2015) yang menjelaskan bahwa genus Avicennia tidak dapat tumbuh dengan baik pada keadaan yang teduh atau berlumpur tebal. Selain faktor substrat, faktor antropogenik juga mempengaruhi keberadaan genus Avicennia (Habdiansyah et al., 2015 dan Mughofar et al., 2018). Berdasarkan nilai dominansi pada stasiun muara Sungai Kumbe menunjukkan tidak adanya dominansi pada vegetasi mangrove di stasiun tersebut. Hal ini berarti kondisi komunitas vegetasi mangrove pada stasiun muara Sungai Kumbe dalam kondisi yang stabil.

Vegetasi mangrove secara khas memperlihatkan adanya pola zonasi (Noor et al., 2006). Robertson \& Alongi, (2000) menjelaskan bahwa zonasi ekosistem dari vegetasi mangrove mencerminkan respon ekofisiologis dari tanaman terhadap satu atau beberapa parameter lingkungan. Secara sederhana, mangrove umumnya tumbuh dalam 4 zona, yaitu pada daerah terbuka, daerah tengah, daerah yang memiliki sungai berair payau sampai hampir tawar, serta daerah ke arah daratan yang memiliki air tawar (Noor et al., 2006). Daerah terbuka adalah daerah mangrove yang berada pada bagian yang berhadapan dengan laut, daerah tengah atau mangrove tengah adalah area mangrove yang terletak di belakang zona terbuka. Zona selanjutnya adalah zona mangrove payau yakni mangrove yang berada di sepanjang sungai berair payau hingga hampir tawar. Di zona ini biasanya didominasi oleh komunitas
Nypa atau Sonneratia, dan yang terakhir adalah zona mangrove daratan yaitu mangrove yang berada di zona perairan payau atau hampir tawar di belakang jalur hijau mangrove yang sebenarnya. Jenis-jenis yang umum ditemukan pada zona ini termasuk Ficus microcarpa, F. retusa, Intsia bijuga, Nypa fruticans, Lumnitzera racemosa, Pandanus sp. dan Xylocarpus moluccensis (Kantor Menteri Negara Lingkungan Hidup, 1993). Zona ini memiliki kekayaan jenis yang lebih tinggi dibandingkan dengan zona lainnya.

Pola zonasi yang terjadi pada pesisir Pantai Nasem (Gambar 9 \& 10) dan Pantai Payumb (Gambar 1113) dimulai dari jenis Avicennia sp. yang berada pada bagian depan disebabkan daerah tersebut merupakan daerah terbuka yang artinya bahwa daerah tersebut berhadapan langsung dengan laut. Hal ini sesuai dengan pendapat Bengen (2004), yang mengemukakan bahwa daerah yang paling dekat dengan laut dan memiliki substrat agak berpasir sering ditumbuhi oleh

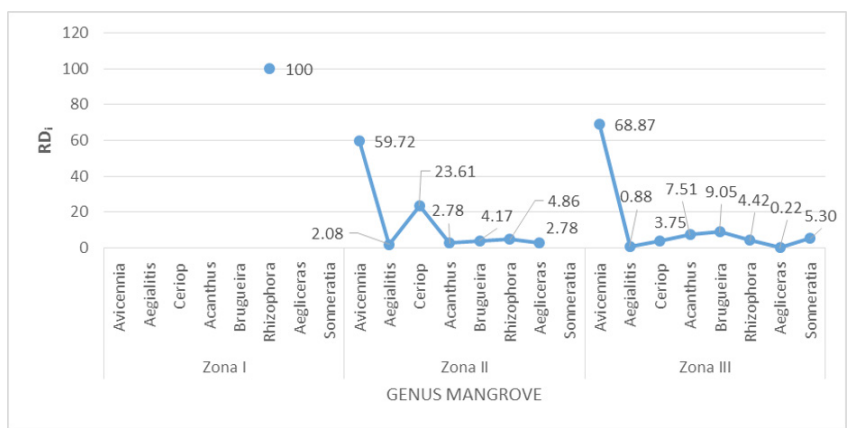

Gambar 8. Grafik kerapatan relatif jenis mangrove muara Sungai Kumbe.

Figure 8. Graph of relative density of mangrove estuaries of the Kumbe River. 

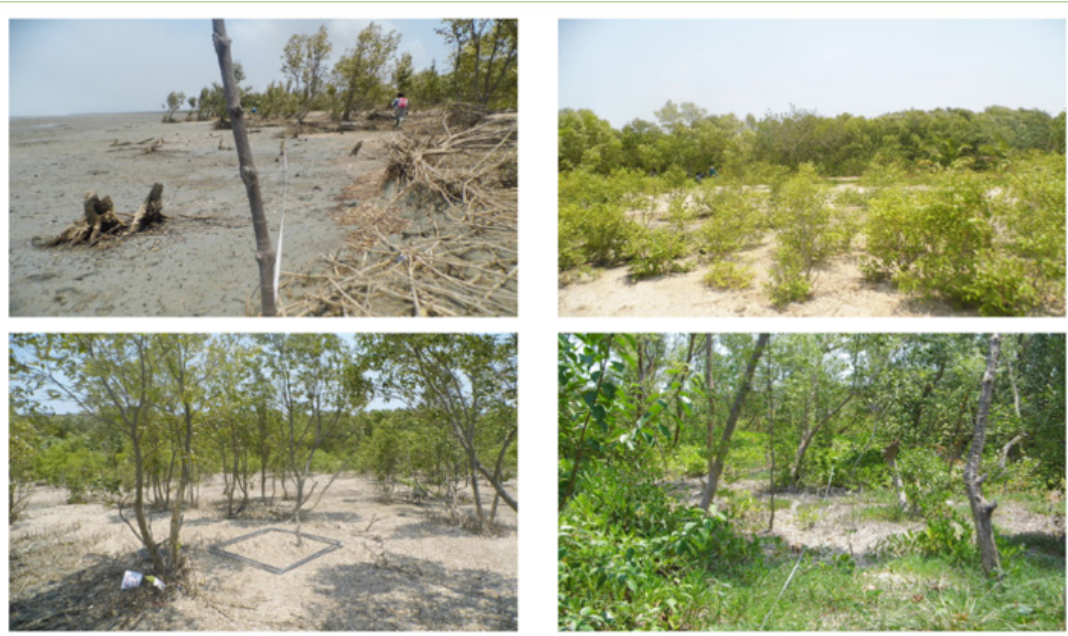

Gambar 9. Kondisi mangrove Pantai Nasem.

Figure 9. Mangrove conditions in Nasem Beach.

Avicennia alba, yang biasanya berasosiasi dengan Sonneratia alba, kemudian diikuti oleh percampuran dari beberapa spesies seperti dari genus Rhizopora, Bruguiera dan jenis Aegialitis annulata.

Keberadaaan anakan sungai pada pesisir Pantai Payumb memberi keunikan tersendiri dengan kehadiran spesies dari genus Rhizophora (Gambar 12). Hal ini menjadi unik dikarenakan keberadaan genus Rhizophora tidak seperti pada daerah lain di Indonesia dimana genus tersebut biasanya berada pada zonasi terdepan tetapi di lokasi ini genus tersebut ditemukan pada kedua sisi badan sungai atau anakan sungai. Dari hasil penelitian vegetasi mangrove pada Pantai Payumb untuk genus Avicennia memiliki jumlah yang paling tinggi, diikuti oleh jenis mangrove lainnya.

Zona tengah pada wilayah pesisir Pantai Payumb dihuni oleh beberapa jenis mangrove seperti Rhizophora $s p$., Bruguiera sp. dan Aegialitis annulata (Gambar 13). Samingan (1980) dalam Khazali (2006) menemukan di area Karang Agung mangrove didominasi oleh jenis Bruguiera cylindrica. Jenis-jenis penting lainnya yang ditemukan di Karang Agung adalah Bruguiera eriopetala, Bruguiera gymnorrhiza, Excoecaria agallocha, Rhizophora mucronata, Xylocarpus granatum dan $X$. moluccensis. Sedangkan menurut hasil penelitian Ibnu Hafizh (2013) zona tengah ditumbuhi atau didominasi oleh jenis Scyphiphora hydrophyllacea dan dapat dijumpai Xylocarpus granatum serta Lumnitzera littorea. Selanjutnya pada zona terakhir dijumpai tumbuhan asosiasi mangrove yang terdiri dari Sonneratia $s p$, Acanthus ebracteatus, Aegialitis annulata, Aegiceras floridum.
Dari hasil penelitian vegetasi mangrove pada muara Sungai Kumbe untuk genus Avicennia memiliki jumlah yang paling tinggi yang berada pada bagian depan menghadap ke arah laut, sebaliknya vegetasi mangrove dari genus Rhizophora memiliki kepadatan tertinggi pada bagian sisi badan Sungai Kumbe dengan lebar dari sisi sungai sekitar $\pm 150 \mathrm{~m}$ (Gambar 14 \& 17).

Zonasi mangrove yang terbentuk pada muara Sungai Kumbe sangat berbeda dengan zonasi mangrove yang ada di pesisir pantai Payumb dan Nasem, dimana zona pertama dihuni oleh genus Rhizophora yang banyak ditemukan di sepanjang aliran Sungai Kumbe pada kedua sisi badan sungai. Jenis ini tumbuh subur dan melimpah. Hal tersebut sesuai dengan pernyataan Supardjo (2008), tentang salah satu jenis Rhizopora yaitu Rhizophora mucronata yang banyak dijumpai di

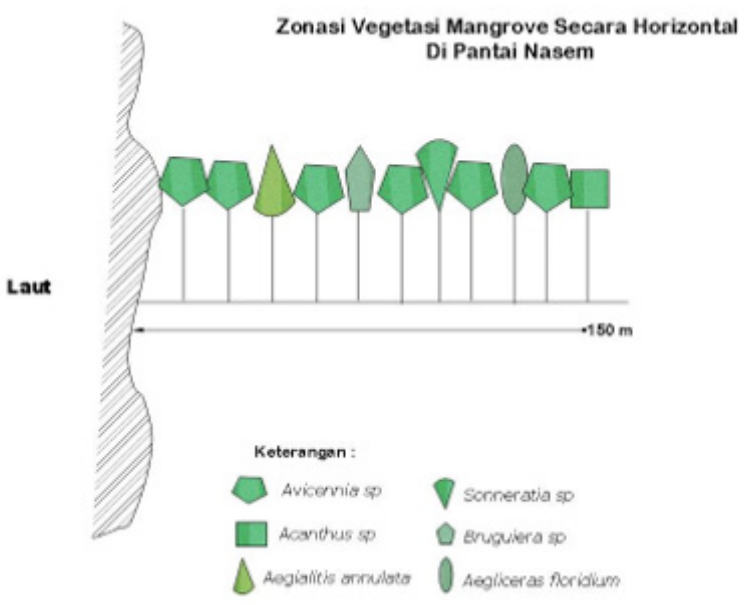

Gambar 10. Kondisi mangrove Pantai Nasem.

Figure 10. Mangrove conditions in Nasem Beach. 


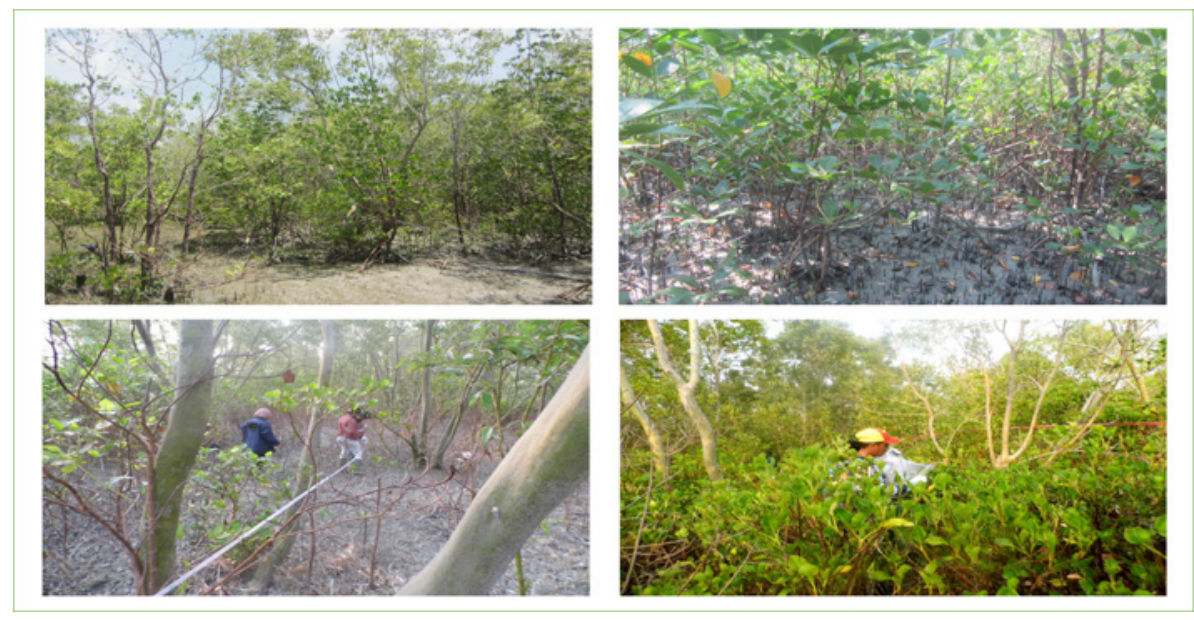

Gambar 11. Kondisi mangrove Pantai Payumb.

Figure 11. Mangrove Payumb Beach.

daerah sungai atau muara yang memiliki lumpur, dan mudah beradaptasi pada kemiringan yang bervariasi. Selanjutnya pada zona tengah (Zona III) di muara Sungai Kumbe yang merupakan zona campuran dimana pada zona ini dihuni oleh beberapa genus mangrove diantaranya adalah Avicennia, Rhizophora, Bruguiera, Sonneratia dan Ceriops (Gambar 15).

Ekosistem mangrove sangat dipengaruhi oleh faktor lingkungan di wilayah sekitarnya (de Jesus, 2012). Penyebaran dan zonasi mangrove dipengaruhi oleh perbedaan faktor lingkungan yang menyebabkan vegetasi mangrove mempunyai struktur yang khas yaitu dengan membentuk lapisan atau zona-zona vegetasi yang berbeda antara satu dengan yang lainnya (Bengen, 2001; Muhsin \& Indrawati, 2008). Mathhijs et al., (1999) menjelaskan terbentuknya zonasi mangrove dapat disebabkan oleh faktor substrat dan tingkat salinitas. Faktor lainnya yaitu sedimentasi juga berkaitan dengan proses reproduksi mangrove yang memerlukan kondisi lingkungan yang cocok untuk penyebaran propagul (Habdiansyah et al., 2015).

Dengan demikian dapat ditarik kesimpulan bahwa setiap daerah memiliki zonasi hutan mangrove yang berbeda-beda. Hal ini disebabkan tiap daerah memiliki tipe substrat yang berbeda sehingga jenis mangrove yang berada pada pesisir pantai dan muara sungai juga akan berbeda. Erwin (2005) menyatakan bahwa secara umum, sesuai dengan kondisi habitat lokal tipe komunitas (berdasarkan jenis pohon yang dominan), mangrove di Indonesia berbeda antara suatu tempat dengan tempat lainnya dengan variasi ketebalan dari beberapa puluh meter sampai dengan beberapa

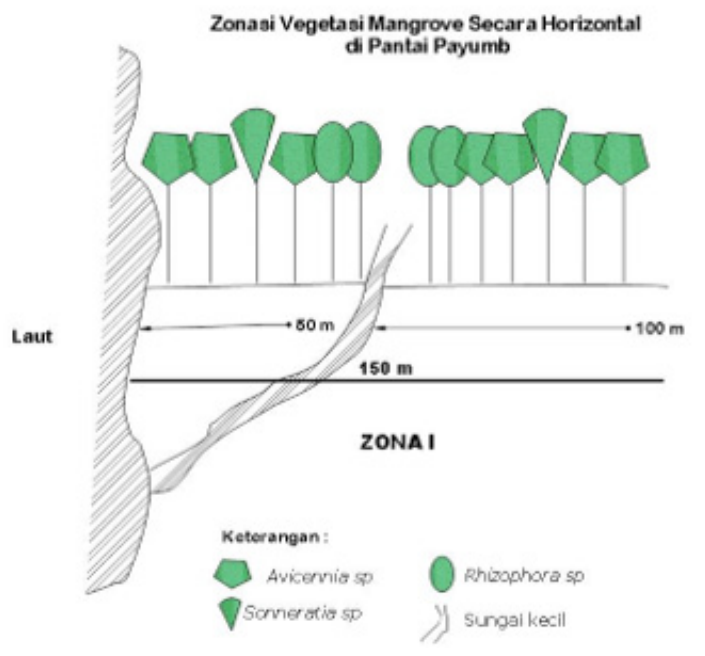

Gambar 12. Pola zonasi mangrove di Pantai Payumb, Zona I. Figure 12. Mangrove zoning patterns in Payumb Beach, Zone I.

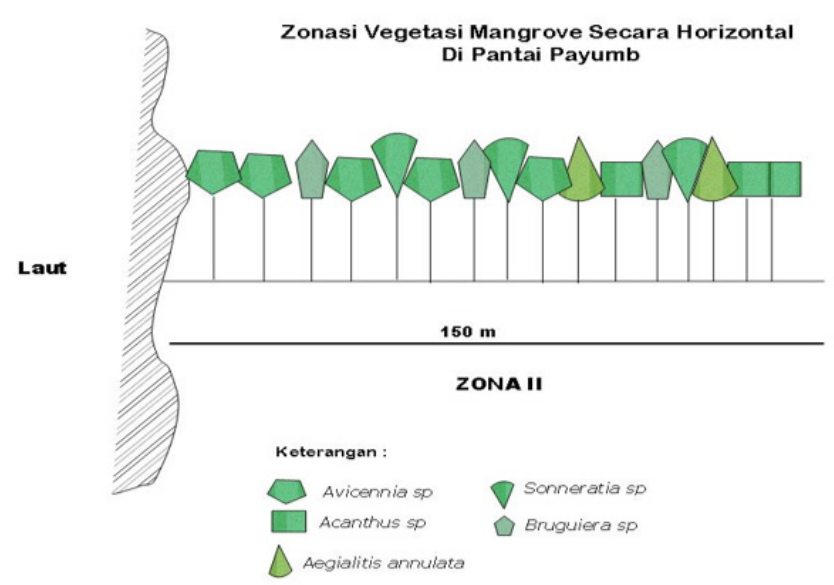

Gambar 13. Pola zonasi mangrove di Pantai Payumb, Zona II. Figure 13. Mangrove zoning patterns in Payumb Beach, Zone II. 

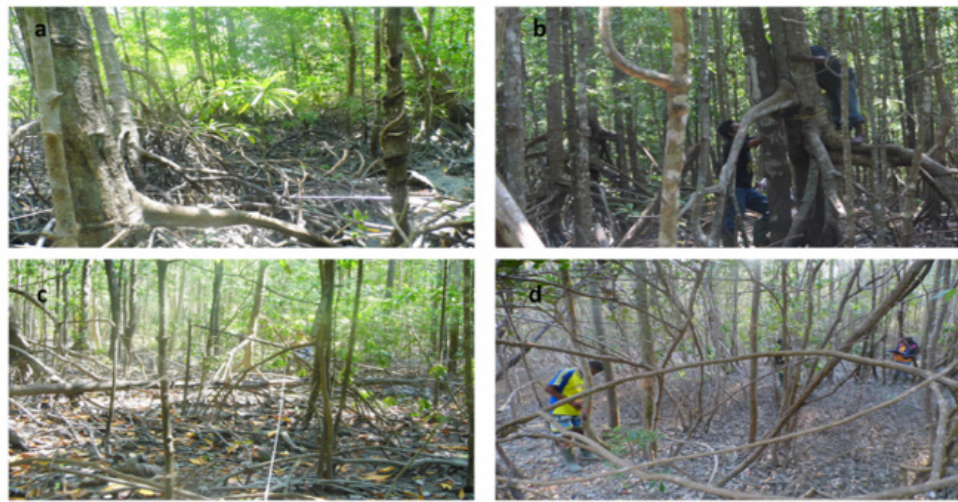

Gambar 14. Kondisi mangrove di muara Sungai Kumbe.

Figure 14. The condition of mangroves in the mouth of the Kumbe River.

kilometer dari garis pantai. Kartawinata \& Waluyo (1987) dalam Erwin (2005), menyatakan bahwa faktor utama yang menyebabkan adanya zonasi pada hutan mangrove adalah sifat-sifat substrat seperti jenis substrat maupun kandungan bahan organiknya, di samping faktor salinitas, frekuensi serta tingkat penggenangan dan ketahanan suatu jenis mangrove terhadap ombak dan arus, sehingga variasi zonasi ini memanjang dari daratan sampai ke pantai. Perbedaan berbagai faktor lingkungan tersebut menyebabkan vegetasi mangrove mempunyai struktur yang khas yaitu dengan membentuk lapisan atau zona-zona vegetasi yang berbeda satu dengan yang lainnya (Muhsin \& Indrawati, 2008) seperti yang ditemukan pada stasiun Pantai Payumb, Pantai Nasem dan pada muara Sungai Kumbe yang memiliki zonasi struktur vegetasi yang berbeda.

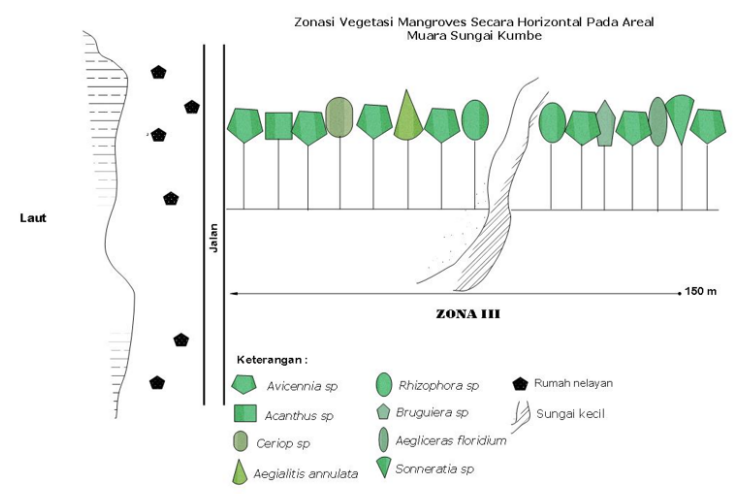

Gambar 15. Pola zonasi mangrove di muara Sungai Kumbe, Zona III.

Figure 15. Mangrove zoning patterns in the mouth of the Kumbe River, Zone III.

\section{KESIMPULAN DAN SARAN}

Vegetasi mangrove di kawasan penelitian di pesisir Kabupaten Merauke yang terdiri dari tiga stasiun penelitian disusun oleh 8 genus dan 15 jenis mangrove. Kerapatan jenis mangrove tertinggi diperoleh dari genus Avicennia pada seluruh zona stasiun penelitian, kecuali pada Zona I stasiun muara Sungai Kumbe kerapatan tertinggi diperoleh dari genus Rhizophora.

Untuk penentuan kondisi komunitas berdasarkan dominansi jenis vegetasi mangrove, stasiun Pantai Nasem dan Pantai Payumb termasuk dalam kriteria komunitas labil. Sebaliknya stasiun muara Sungai Kumbe memiliki kondisi komunitas vegetasi yang stabil.

Zonasi ekosistem mangrove pada Kabupaten Merauke terdiri dari dua tipe zonasi. Pada daerah pesisir yang berhadapan langsung dengan laut, genus Avicennia

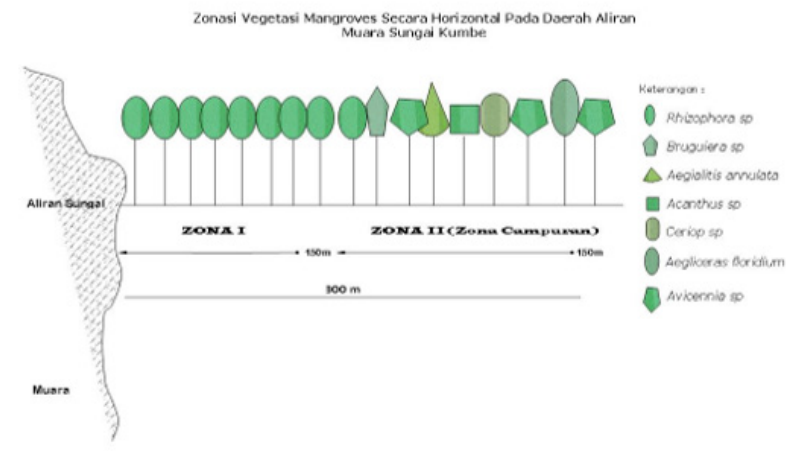

Gambar 16. Pola zonasi mangrove di muara Sungai Kumbe, Zona I dan Zona II.

Figure 16. Mangrove zoning patterns in the mouth of the Kumbe River, Zone I and Zone II. 


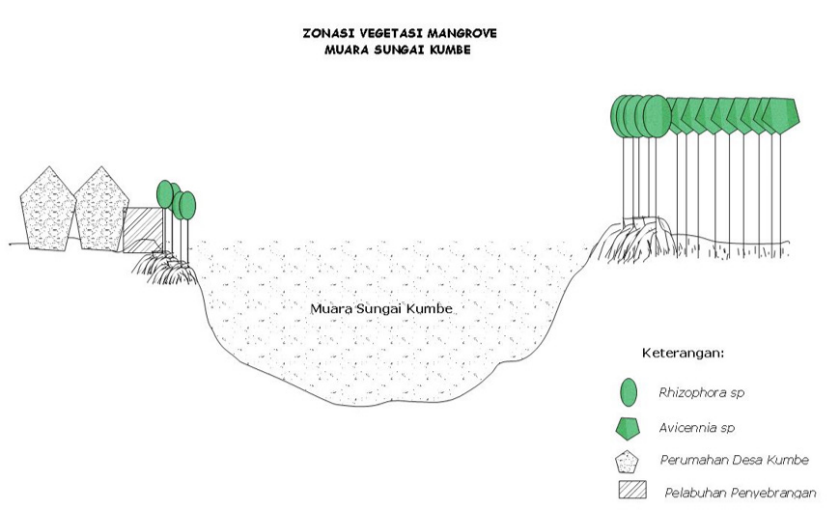

Gambar 17. Tampak depan zonasi mangrove di muara Sungai Kumbe.

Figure 17. Front view of mangrove zoning in the mouth of the Kumbe River.

merupakan pioneer dalam membentuk zonasi vegetasi mengrove. Sebaliknya pada daerah sungai, genus Rhizophora menjadi pioneer membentuk zonasi pada kedua sisi badan sungai.

\section{UCAPAN TERIMA KASIH}

Makalah ini adalah bagian dari kegiatan riset "Identifikasi Potensi Ekonomi Sumberdaya Laut dan Pesisir Kabupaten Merauke" tahun 2015, dengan penanggung jawab Litbang Dr. Taslim Arifin.

\section{DAFTAR PUSTAKA}

Aini, H. N., Rusdiana, O., \& Mulatsih, A. (2015). Identifikasi Tingkat Kerawananan Degradasi Kawasan Hutan Mangrove Desa Muara, Tangerang, Banten. Jurnal Pengelolaan Sumberdaya Alam dan Lingkungan, 5(1), 79-86.

Barbour, M. G., Burk, J. H., \& Pitts,W. D. (1987). Terrestrial plant ecology. second edition. Menlo park CA: The Benjamin Cumming Pub co. Inc

Bengen, D. G. (2002). Ekosistem dan sumberdaya alam pesisir dan laut serta prinsip pengelolaannya. Bogor: Pusat Kajian Sumberdaya Pesisir dan Lautan, IPB.

Bengen, D. G. (2004). Pedoman teknis; Pengenalan dan Pengelolaan Ekosistem Mangrove. PKSPL-1PB. Bogor.

Bengen, D. G., (2004). Sinopsis Ekosistem dan Sumberdaya Alam Pesisir. Pusat Kajian Sumberdaya Pesisir dan Lautan - Institut Pertanian Bogor. Bogor, Indonesia.

Bengen, D. G. (2001). Sinopsis Ekosistem dan Sumberdaya Alam Pesisir dan Laut. Pusat Kajian Sumberdaya Pesisir dan Laut, Institut Pertanian Bogor.

Brower, J., \& Zar, J. (1989). General Ekology, Field and Laboratory Methods. Brown Company Publ. Dubugue. Iowa. 3.
Chapman, V.J. editor., (1977). Wet Coastal Ecosystems. Ecosystems of the World: 1. Elsevier Scientific Publishing Company, 428 hal.

Darmadi, M., Lewaru, W., \& Khan, A. M.A. (2012). Struktur Komunitas Vegetasi Mangrove Berdasarkan Karakteristik Substrat di Muara Harmin Desa Cangkring Kecamatan Cantigi Kabupaten Indramayu. Jurnal Perikanan dan Kelautan, 3(3), 347-358.

de Jesus, Antonio. (2012). Kajian Kondisi Ekosistem Mangrove Di Sub Distrik Bazartete Distrik Liquisa Timor-Leste. Jurnal KELAUTAN, 5(2), 117 -126.

Fachrul, M. F. (2007). Metode Sampling Bioekologi. Sinar Grafika Offset. Jakarta.

Fadli, Khairijon, \& Sofiyanti, N. (2015). Analisis Vegetasi Avicennia sp. dan Karakteristik Sedimen di Kawasan Mangrove Desa Sungai Rawa Kecamatan Sungai Apit Kabupaten Siak, Riau. JOM FMIPA, 2(1), 23-34.

FAO. (1982). Management and Utilization of Mangrove in Asia and the Pasific. FAO Enviromental paper III. Rome.

Firly Talib. (2008). Struktur dan pola zonasi (sebaran) mangrove serta makrozoobenthos yang berkoeksistensi di desa tanah merah dan oebelo kecil. Skripsi. kabupaten kupang.

Habdiansyah, P., Lovadi, I., \& Linda, R. (2015). Profil Vegetasi Mangrove Desa Sebubus Kecamatan Paloh Kabupaten Sambas. Protobiont, 4(2), 9-17

Halidah., \& Kama, H. (2013). Penyebaran Alami Avecennia Marina(Forsk) Vierh dan Sonneratia Alba Smith Pada Substrat Pasir di Desa Tiwoho Sulawesi Utara. Indonesian Rehabilitations Forest Journal, 1(1), 5158.

Haya, N., Zamani, N. P., \& Soedharma, D. (2015). Analisis Struktur Ekosistem Mangrove Di Desa Kukupang Kecamatan Kepulauan Joronga. Jurnal Teknologi Perikanan dan Kelautan, 6(1), 79-89.

Jamili, D., Setiadi., Qayim, I., \& Guhardja, E. (2009). Struktur dan Komposisi Mangrove di Pulau Kaledupa Taman Nasional Wakatobi, Sulawesi Tenggara. ILMU KELAUTAN, 14(4), 197-206.

Kementerian Lingkungan Hidup., (2004). Keputusan Menteri Lingkungan Hidup Nomor 201 Tahun 2004 tentang Baku Baku Kerusakan Mangrove. Jakarta: Kementerian Lingkungan Hidup.

Khazali, M. (2006). Panduan pengenalan mangrove PHKA/ WI-IP, Bogor.

Kint, A. (1934). De luchtfoto en de topografische terreingesteldheid in de mangrove. De Tropische Natuur, 23, 173-189.

Kusmana, C. (1997). Metode survey vegetasi. Bogor. PT Penerbit Institut Pertanian Bogor.

Kusmana, C., Onrizal., \& Sudarmadji. (2003). Jenis-jenis Pohon Mangrove di Teluk Bintuni Papua. Fakultas Kehutanan IPB dan PT Bintuni utama murni wood industries.

Lestari, F. (2014). Komposisi Jenis Dan Sebaran Ekosistem Mangrove Di Kawasan Pesisir Kota Tanjungpinang, Kepulauan Riau. Dinamika Maritim, 4(1), 68-75. 
Mac Nae, W. (1968). A General Account of Fauna and Flora of Mangrove Swamps and Forest in The IndowestPacific Region. dalm: Adv. Mar. Biol, 6,73-270.

Mughofar, A, Masykuri, M., \& Setyono, P. (2018). Zonasi dan Komposisi Vegetasi Hutan Mangrove Pantai Cengkrong Desa Karanggandu Kabupaten Trenggalek Provinsi Jawa Timur. Jurnal Pengelolaan Sumberdaya Alam dan Lingkungan, 8(1), 77-85.

Muhsin \& Indrawati. (2008). Distribusi dan Kepadatan Jenis Vegetasi Mangrove Menurut Tingkatan Pertumbuhan di Wilayah Pesisir Kabupaten Kolaka Provinsi Sulawesi Tenggara. Volume 16 Nomor 02 Juli : 128136

Noor, Y. R., Khazali, M., \& Suryadiputra, I. N. N. (2006). Panduan Pengenalan Mangrove di Indonesia. PHKA/WI-IP, Bogor.

Pramudji. (2008). Mangrove di Indonesia dan Upaya Pengelolaannya. Orasi Pengukuhan Profesor Riset Bidang Ekologi Laut P20-LIPI.31 hal.

Rahman, D., Yanuarita., \& Nurdin. N. (2014). Struktur Komunitas Mangrovedi Kabupaten Muna. Torani (Jurnal Ilmu Kelautan dan Perikanan), 24(2), 29-36.

Robertson, A. I. \& Alongi, D. M. (Eds.). (2000). Coastal and Estuarine Studies Series 41 : Tropical Mangrove. American Geophysical Unio. Washington

Samsumarlin, I., Rachman., \& Toknok B. (2015). Studi Zonasi Vegetasi Mangrove Muara di Desa Umbele Kecamatan Bumi Raya Kabupaten Morowali Sulawesi Tengah.Warta Rimba, 3(2), 148-154.

Supardjo, M. N. (2008). Identifikasi Vegetasi Mangrove Di Segoro Anak Selatan, Taman Nasional Alas Purwo, Banyuwangi, Jawa Timur. Jurnal Saintek Perikanan, $3(2), 9-15$.

Suryawan, F. (2007). Keanekaragaman Vegetasi Mangrove Pasca Tsunami di Kawasan Pesisir Pantai Timur Nangroe Aceh Darussalam Mangrove vegetation diversity after tsunami in east coastal area of Nangroe Aceh Darussalam. BIODIVERSITAS, 8(4), 262-265.

Tuwo, A. (2011). Pengelolaan Ekowisata Pesisir dan Laut. Penerbit: Brilian Internasional, Surabaya.

Usman, L., Syamsuddin., \& Hamzah, S. N. (2013). Analisis Vegetasi Mangrove di Pulau Dudepo Kecamatan Anggrek Kabupaten Gorontalo Utara. Jurnal Ilmiah Perikanan dan Kelautan, 1(1), 11-17.

Yuningsih, E., Simbala, H. E. I., Kandou, F. E. F., \& Saroyo. (2013). Keanekaragaman Vegetasi Mangrove di Pantai Tanamon Sulawesi Utara. Jurnal Bios Logos, 3(2),78-84.

JURNAL KELAUTAN NASIONAL, Vol. 14, No 3, Desember 2019, Hal. 165-178 